University of Chicago Law School

Chicago Unbound

\title{
Mechanisms for Eliciting Cooperation in Counter-Terrorism Policing: Evidence from the United Kingdom
}

Tom R. Tyler

Stephen J. Schulhofer

Aziz Huq

Follow this and additional works at: https://chicagounbound.uchicago.edu/public_law_and_legal_theory

Part of the Law Commons

Chicago Unbound includes both works in progress and final versions of articles. Please be aware that a more recent version of this article may be available on Chicago Unbound, SSRN or elsewhere.

\section{Recommended Citation}

Tom R. Tyler, Stephen J. Schulhofer \& Aziz Huq, "Mechanisms for Eliciting Cooperation in CounterTerrorism Policing: Evidence from the United Kingdom" (University of Chicago Public Law \& Legal Theory Working Paper No. 340, 2011).

This Working Paper is brought to you for free and open access by the Working Papers at Chicago Unbound. It has been accepted for inclusion in Public Law and Legal Theory Working Papers by an authorized administrator of Chicago Unbound. For more information, please contact unbound@law.uchicago.edu. 


\title{
CHICAGO
}

Public LaW ANd Legal Theory Working Paper No. 340

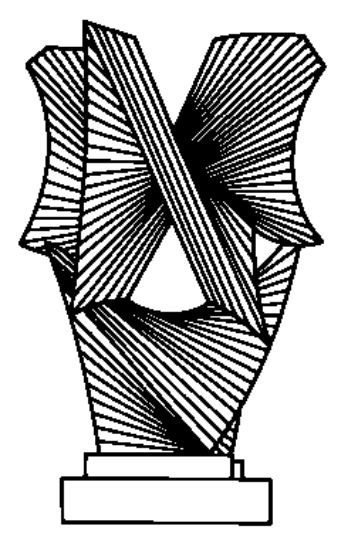

\section{MECHANISMS FOR ELICITING COOPERATION IN COUNTER- TERRORISM POLICING: EVIDENCE FROM THE UNITED KINGDOM}

\author{
Aziz Z. Huq, Tom R. Tyler, and Stephen J. Schulhofer \\ THE LAW SCHOOL \\ THE UNIVERSITY OF CHICAGO
}

February 2011

This paper can be downloaded without charge at the Public Law and Legal Theory Working Paper Series: http://www.law.uchicago.edu/academics/publiclaw/index.html and The Social Science Research Network Electronic Paper Collection. 


\title{
Mechanisms for eliciting cooperation in counter-terrorism policing: Evidence from the United Kingdom
}

\author{
Aziz Huq \\ Tom R. Tyler \\ and \\ Stephen J. Schulhofer *
}

* Tom Tyler: New York University, School of Law and Psychology Department. Stephen Schulhofer: New York University, School of Law. Aziz Huq: University of Chicago Law School. Correspondence: huq@uchicago.edu; 1111 East $60^{\text {th }}$ Street, Chicago, IL 66037, USA (+1-773-702-9566(p); +1-773-702-0730(f)) . 


\begin{abstract}
This study examines the effects of counterterrorism policing tactics on public cooperation amongst Muslim communities in London, U.K. It tests a procedural justice model developed in the context of studying crime control in the United States. The study reports results of a randomsample survey of 300 closed and fixed response telephone interviews conducted in Greater London's Muslim community in February and March 2010. It tests predictors of cooperation with police acting against terrorism. Specifically, the study provides a quantitative analysis of how perceptions of police efficacy, greater terrorism threat, and the choice of policing tactics predict the willingness to cooperate voluntarily in law enforcement efforts against terrorism. Cooperation is defined to have two elements: a general receptivity toward helping the police in anti-terror work, and a specific willingness to alert police upon becoming aware of a terrorrelated risk in a community. We find that procedural justice concerns prove better predictors for both measures of cooperation in counter-terrorism policing among British Muslims. Unlike previous studies of policing in the United States, however, we find no correlation between judgments about the legitimacy of police and cooperation. Rather procedural justice judgments influence cooperation directly.
\end{abstract}




\section{Introduction}

After terrorist attacks in New York, London, Glasgow, Madrid, and other major urban centers, police in the United States and Europe have been tasked with dual functions of crime control and terrorism prevention. Policing responses to the newly perceived terrorism threat has concentrated on Muslim communities of South Asian, Middle Eastern, and North African origin. These communities on the one hand have been subject to more intensive and burdensome police scrutiny and intrusion. Law enforcement has also cultivated ties with Muslim communities to secure cooperation in obtaining information about potential terrorist recruitment and planning, and to overcome the cultural and linguistic differences that increase the cost to police of gathering information absent cooperation from members of the Muslim community. Such cooperation has already proved important in preventing several terrorism attempts (Schulhofer et al. 2011).

How do the choice of investigative tactics and the perception of police as either effective or ineffective, and either discriminatory or fair, interact with public cooperation? This study addresses the relationship between counterterrorism policing tactics and public cooperation within Muslim communities in London, U.K. We report here the results of a random-sample survey of 300 closed and fixed response telephone interviews conducted in Greater London in February and March 2010 testing predictors of cooperation among the British Muslim community. This is the first study to examine empirically the dynamics of policing against terror in this important U.K. population. Specifically, the study provides a quantitative analysis of how different policing tactics correlate to different levels of willingness to cooperate voluntarily with police in efforts against terrorism. As discussed below, cooperation is defined in the study to have two elements: first, a general receptivity toward helping the police in anti-terror work, and 
second, the specific willingness to alert police upon becoming aware of a terror-related risk in a community.

Drawing on this data, we evaluate three potential explanations for public cooperation by British Muslim communities with police. The first two mechanisms are derived from previous studies (largely conducted in the United States) of public cooperation with police in ordinary crime control efforts and of compliance with laws. First, studies have hypothesized an instrumental mechanism whereby people estimate and act on the basis of net expected benefits or costs from cooperation with the law (Becker 1976, Posner 1985). Second, other studies have identified "procedural justice" explanations for public cooperation with law enforcement. The procedural justice model posits a two-stage explanation: People respond to their belief that police are a legitimate authority, which in turn is a function of the fairness and procedural justice of police procedures in formulating and implementing policies (MacCoun 2005; Tyler 2006b; Tyler and Huo 2002). This study independently tests both elements of this mechanism.

The third explanation for public cooperation — examined for the first time in this studyis political and religious ideologies. We use the term "ideology" to refer to normative judgments derived from systemic judgments about political systems (Kennedy 1979). Ideology so defined is a potentially relevant factor in this study because of the difference between ordinary crime and terrorism: Terrorism is typically motivated by a political or religious critique of the government. Its use and its acceptance are potentially influenced by value-based judgments about the appropriateness of using violence toward innocent people to achieve political and religious objectives. Therefore, attitudes toward terrorism may also be motivated by allegiance to external political communities defined in either religious or political terms. 
London is an appropriate locus of a study whose purpose is testing the strength of these explanations. It was the location of a major successful terrorist attack in July 2005. There have been numerous arrests of British Muslims alleged to be connected to terrorist conspiracies (Pargeter 2008). Further it has a substantial Muslim population. A 2001 census estimated that 8.5 percent of Londoners were Muslim (Mayor of London 2006).

On-the-ground policing has also changed in London in response to terrorist threats. The British parliament enacted omnibus anti-terrorism laws in 2001, 2005, 2006, and 2008, supplementing terrorism-related powers passed into law in 2000 (Mythen et al. 2009; Donohue 2008). These laws expanded police authority on the ground. Section 44 of the 2000 Terrorism Act, for example, vested police with controversial authority to engage in investigative street stops based upon their discretionary risk judgments (Walker 2009). Counter-terrorism intelligence officers have been installed at the borough level across London (Clarke 2007). The Home Office's Office for Security and Counter Terrorism also distributes to local police "heat maps" identifying areas of high risk for "producing violent extremists" (Turley 2007). New antiterrorism policing powers in Britain have further led to allegations that police direct disproportionate resources toward Muslim and South Asian communities or otherwise engage in “profiling” (Chakrabarti 2007; HCLCG 2010; Kundnani 2009; Mirza et al. 2007, Travis 2010).

In summary, London is characterized by an arguably high terrorism threat level, by the emergence of new and potentially intrusive forms of policing, and by a religiously/ethnically diverse population possibly holding sympathetic views about terrorism and negative evaluations of the police and the UK government more generally. It therefore provides a plausible location in which to study competing explanations for public cooperation in anti-terrorism policing. 
The paper has six sections. The first explores the role of public cooperation in ordinary counter-terror policing. The second identifies different possible mechanisms for eliciting cooperation. The third section briefly reviews recent changes to terrorism-related policing in the United Kingdom and surveys existing research about their effect on British Muslim communities. The fourth outlines the methodology of the study and its limitations. The fifth section presents the data. The final section discusses the results and draws implications for further study.

\section{Cooperation with Police}

Cooperation between police and communities is almost uniformly viewed as good. Policing specialists and scholars have long recognized the value of cooperation in generating social order. The Metropolitan Police's founders stressed public cooperation (Reich 1956). More recently, studies from the United States suggest that policing strategies eliciting community cooperation have a potentially more significant effect on ordinary crime than strategies that do not involve the community (Bureau of Justice Assistance 1994, Hughes and Rowe 2007).

Does public cooperation matter to the success of policing against terror as well to policing against ordinary crime? This is a question subject to continuing debate, but the weight of evidence suggests that cooperation is at least as valuable to the police in the counterterrorism context as in the crime control context, and is therefore worth studying. In fact, it may be of greater value because the police are more likely to be "outsiders" within the Muslim community.

On the one hand, some policing experts have argued for the adaption of a "broken windows" policing approach to countering terrorism (Kelling and Bratton 2006). Drawing inspiration from what they characterize as an Israeli approach to counter-terrorism policing, they 
argue for creation of a comprehensive "terrorist unfriendly" environment through cameras, random screenings, and sensors. Others use rational choice models to propose group-based sanctions against communities in which terrorists operate (Garoupa et al. 2006). These proposals implicitly discount the value of cooperation from the ethnic and religious communities generally targeted in terrorism investigations. This is the case because such "unfriendly" policies seem likely to undermine cooperation. For example, the fourth of Charles Rowan and Richard Mayne's nine articles of U.K. policing was: "To recognize always the extent to which the cooperation of the public can be secured diminishes proportionally to the necessity of the use of physical force and compulsion for achieving police objectives” (Reith 1956).

On the other hand, empirical evidence and police practice provide grounds for questioning a preference for harsh measures in counterterrorism policing (Schulhofer et al, 2011). First, empirical claims by "broken windows" advocates have been subject to comprehensive criticism even in the crime control context (Harcourt 2001; Zimring 2011). Second, although "very little is known about the nature and effectiveness of police counterterrorism strategies (Lum et al. 2009)", empirical evidence from analogous contexts suggests that counterterrorism strategies that depend on coercive measures have limited effects. Lafree, Dugan and Korte, for example, estimate the deterrence effects and backlash effects of six policing and military interventions in the Northern Ireland context between 1969 and 1992 (Lafree et al. 2009). While their study does not directly address cooperation it investigates the predictors of terrorist violence. Across the six interventions, Lafree et al. found a backlash effect in three cases-i.e., that these interventions increased terrorist violence-deterrence effects in one case, and two interventions with no statistically significant impact. Their findings suggest that a deterrence-based model of harsh measures against terrorism can be counterproductive. 
Their result is supported by Berrebi and Klor's analysis of dynamic interactions between terrorism in the Israel-Palestine conflict and electoral outcomes, which found no correlation between more aggressive policies and reductions in terrorism levels (Berrebi and Klor 2006).

Third, counterterrorism policing strategy in the United Kingdom recognizes the value of cultivating public cooperation within British Muslim communities. A "Muslim Contact Unit" has been formed in London for outreach to groups that otherwise would have little contact with the state (Lambert 2007). In 2007, Peter Clarke, then Deputy Assistant Commission for the Counter Terrorism Command of the Metropolitan Police and National Coordinator of Terrorist Investigations stated: "One of the challenges for counter-terrorist policing is ... not [to] lose our local connections within communities. We must include the flow of information coming from communities" (Clarke 2007).

Some empirical studies of terrorism predict that public cooperation will be especially valuable to counterterrorism policing. Terrorism is a relatively dispersed and infrequent phenomenon. It poses a threat to a near-infinite range of symbolic targets, typically using operatives with no prior record of terrorist activity. As a result, accurate and timely information to distinguish genuine threats from background noise has great value. The difficulty of identifying real risks in communities and cultures that are unfamiliar to law enforcement community may mean that public cooperation is even more important than in the crime control context (Huq 2011). Post-2001 terrorist attempts have often involved individuals who developed connections with terrorist organizations and violent plans while living in European or Britain Muslim communities (Roy 2004, Sageman 2004, Sageman 2008). To the extent that terrorist groups seek either to recruit or hide within co-religionist communities, cooperation can provide 
information at lower cost and with fewer negative side effects than coercive or intrusive forms of intelligence gathering (Hasini et al. 2009).

It is therefore plausible that cooperation from Muslim communities in London or cities of its ilk is valuable in the case of counterterrorism just as public cooperation is valuable to ordinary crime control. Understanding the mechanisms by which such cooperation is either produced or mitigated is therefore worthwhile.

\section{Mechanisms of Public Cooperation with Police}

The predictors of public cooperation with police in ordinary crime-control efforts have been the subject of past studies in the United States. We draw on those studies to identify potential mechanisms that could explain variance in cooperation within the population of British Muslims sampled in our study. Previous research suggests two principal mechanisms, one instrumental and the other normative. We further recognize that terrorism is importantly different from ordinary crime. Thus it is important to include a third potentially important factor shaping cooperation. Terrorism has an ideological dimension that ordinary crime typically does not. We therefore propose a third mechanism that reflects the difference between crime and terrorism.

The first possible explanation for public cooperation with police is instrumental and grounded in a rational-choice model of human decision-making. In An Introduction to the Principles of Morals and Legislation, Bentham outlined an account of punishment as justified when expected cost outweighed expected benefits (Bentham 1996). This account implies that people cooperate with law enforcement in expectation of net gains from compliance-e.g., increased safety—or of net losses from noncooperation-e.g., increased unwelcome and burdensome attention from law enforcement (Becker 1976, Posner 1985). Police following the 
instrumental model encourage cooperative behavior by making community residents' cooperation more rewarding, for example by showing police are effective in fighting crime (Kelling \& Coles, 1996), by punishing more rule breakers (Bayley \& Mendelsohn, 1968; Nagin, 1998), or by channeling unwelcome policing resources and attention toward uncooperative communities.

We focus on a simple instrumental model because it reflects an important strand in British policing. An instrumental approach to policing based on a simple rationale of deterrence dominated British policing policy through the 1980s (Hough 2007; Mclaughlin et al. 2001). In the 1990s, instrumental logic motivated the British government's model of 'new public managerialism'. This approach to policing emphasized tangible results, targets, league tables, costing and market testing of activities (McLaughlin et al. 2001). In a quintessentially instrumental approach to crime control, new public managerialism "pric[ed]" offenses to calibrate optimal sanctions (Garland 2001, 130). It is therefore appropriate to ask whether a straightforward cost-benefit approach of this type explains public cooperation in the case of new efforts to combat terrorism.

The second account of public cooperation with the police is based on ideas of procedural justice. This model has two elements. It first extrapolates from Max Weber's identification of legitimacy as a necessary antecedent of the state's preservation of social order (Tyler 2006a). Weber stipulated that the state possessed a monopoly on the use of force, but nevertheless contended that it could not preserve order through force alone. Legitimacy, Weber argued, provided the needed supplement (Weber 1968). A recent survey defines a legitimate authority as one "regarded by people as entitled to have its decisions and rules accepted and followed by others (Skogan \& Frydl 2003, p. 297)”’. 
The second element connects legitimacy to the procedural justice of police behavior. Research on legitimacy in the United States shows that the legitimacy of an institution correlates with the extent to which it behaves with procedural justice (Sunshine \& Tyler 2003a, Tyler 2006b). Procedural justice has two key elements: first, the quality of the process used to make decisions and second, the quality of the interpersonal treatment that people receive when dealing with authorities (Tyler 2006b). The measurement of procedural justice therefore looks to several aspects of institutional behavior, including whether officials allow people to provide input before making decisions; whether officials exercise authority in neutral and consistent ways; whether they are perceived as trustworthy; and whether they treat people with whom they deal with dignity and respect (Tyler 2000, Tyler 2006b). In this study, we distinguish and address separately the legitimacy and procedural justice elements in this model.

Originally developed to model and explain variance in compliance with the law, the procedural justice model has been extended to cooperation with law enforcement entities (Sunshine and Tyler 2003a; Tyler and Fagan 2008). Procedural justice studies have further been extended to interactions between US police and racial minorities (Sunshine and Tyler 2003a, 532; Tyler 2005; Tyler and Fagan 2008; Tyler and Huo, 2001). The model has also been replicated outside the US (Tyler et al. 2000; Tyler 2007b). For example, one study found support for extra-legal law enforcement (vigilantism) in Ghana to be explained by procedural justice but not by measures of police effectiveness (Tanekebe 2009). There is some evidence that procedural justice effects are not found in all non-American/European cultures. Studies conducted in China, for example, suggest that procedural justice effects are not found in work settings in that context (Brockner et al. 2001). 
In the crime-control context, the procedural justice account has been found to perform better than the instrumental model in predicting both compliance with the law and cooperation with law enforcement authorities. An extensive literature in the United States consistently finds correlations between procedural justice and legitimacy on the one hand, and between legitimacy and compliance with the law on the other (Tyler 2009). In respect to ordinary policing, empirical studies by contrast find only weak support for instrumental accounts of either cooperation with law enforcement or compliance with the law (Tyler 2006b, 2009; Tyler 2007; Tyler \& Fagan, 2008; Sunshine \& Tyler, 2003).

The procedural justice model has been extended in the United States to the counterterrorism context. In a study with a similar Muslim sample, Tyler, Schulhofer and Huq (2010) analyze the interaction between American law enforcement and Muslim Americans in New York City. They find strong procedural justice effects on cooperation both generally and when cooperation is defined as willingness to alert police of potentially suspicious behavior (Tyler et al. 2010). They also find that the effect of procedural justice is mediated through legitimacy as has been the case in other procedural justice studies. By contrast, they find no statistically significant correlation between expected costs or benefits of counter-terrorism and cooperation. This New York City study provides threshold ground for thinking that models of public cooperation in the crime-control context can be profitably transferred to the counterterrorism context.

The American and the European criminal justice contexts, however, are different in ways that might influence the dynamics of cooperation (Whitman 2003). The relationship between the Muslim population and dominant social institutions is also not the same, with the United States distinctive in its history of assimilating minority populations that in other countries continue 
separate traditions and loyalties across generations. It cannot be assumed, therefore, that a result generated in the American context will be generalizable to a European context.

This study also allows a third set of hypotheses to be tested. This third model focuses upon ideology and suggests that individuals will be less willing to cooperate with police against terrorism when they have increasingly positive assessments of either the political causes espoused by terrorists or the religious justifications invoked by terrorist organizations for violence against civilians. These are "ideological" explanations for cooperation. They predict that noncooperation will be linked to an acceptance of the general normative framework and the specific political goals offered by terrorists. In this sense terrorism is a recent manifestation of a long history of conflicts between the state and people motivated by religious values (Kelman and Hamilton 1989) or alternative political ideologies (Klandermans 1997).

The most significant terrorist organization for the purpose of this study is al Qaeda. Its claims are based on appeals to religious solidarity and to shared opposition of American, British, or European foreign policies (Habeck 2007; Kepel and Milelli 2010). Among al Qaeda's recruitment tools is on-line literature espousing the Salafist strand of Islamic thought (Cronin 2010, 173). Al Qaeda literature also emphasizes Muslim disagreement with foreign policy decisions by American and European government policy, such as the Israeli-Palestinian conflict and the conflicts in Iraq, Afghanistan, and Chechnya, decisions widely opposed in the Muslim community (Kepel 2004; Roy 2008, 156-57). Domestic policy disagreements also figure in al Qaeda's arguments (Mamdani 2005). In a 2004 “Message to the American People,” for example, Osama bin Laden invoked the "despotism and contempt for freedom [of] the Patriot Act (Kepel and Milelli 2010, 74)". Both political and religious differences, therefore, are potentially relevant for predicting attitudes toward the legitimacy of terrorism. Because of their relevance, they make 
shape cooperation against terrorism differently than attitudes to ordinary crime (for a direct comparison using U.S. data see Huq, Tyler and Schulhofer, 2011).

In labeling these explanations "ideological", we follow the terminology of the U.K. government. In the 2010 statement of national counterterrorism policy, that government identified the "ideology that supports violent extremism" as a key source of terrorist risk (HM Government 2010, 12). Counterterrorism strategy in Britain addresses this ideology through tactics that focus on addressing political and religious ideology. The U.K. government has funded debates on both political and religious matters to counteract al Qaeda recruitment efforts. Part of the British government's "Prevent" strategy, for example, has been the funding of "prominent domestic and international Islamic scholars" to promote a "Radical Middle Way," and effort by the Foreign and Commonwealth Office "to take part in discussions with British Muslims on foreign policy issues of concern (HM Government 2009, 14-18). These efforts have been controversial. They are criticized as favoring more religious Muslims over more secular ones, and disadvantaging non-Muslim South Asians and Caribbean groups (HCCLGC 2010).

"Ideology" encompasses several elements. It is necessary to be more precise in order to operationalize it for the purposes of this study. Ideological explanations generate three possible hypotheses concerning cooperation relevant to this study. First, cooperation may be correlated with views on foreign policy decisions that al Qaeda focuses upon, such as the Middle East conflict, the wars in Iraq and Afghanistan, and the detention facility at Guantánamo Bay. Second, cooperation may be correlated with acceptance of the means used by terrorists. In particular, terrorism involves the willingness to kill people at best marginally linked to the policies terrorists oppose and most typically considered to be innocent bystanders. Thirdly, cooperation may decline with increased religious (specifically Muslim) identity because of feelings of solidarity 
with the culture from which most terrorists emerge and whose imagery and values are used by terrorists to explain and justify their actions. The questionnaire used in this study allows us to test each of these three hypotheses.

\section{The Context of Policing against Terrorism in the United Kingdom}

This section provides background for this study. It summarizes past empirical research into the policing of British Muslim communities. Past studies, however, provide little data about the relative strength of possible explanations for cooperation in counterterrorism policing. They do suggest, however, that the population that this study focuses upon should contain a diversity of views about the efficacy and fairness of police and a diversity of normative judgments about the British state and terrorism.

Large Muslim populations have resided in the United Kingdom since the 1960s (Ansari 2004). The 2001 National Census found 1.6 million Muslims; 68 percent were of South Asian ethnicity (Choudhury et al. 2005, Fetzer and Soper 2005, Hellyar 2007). Studies of British Muslims suggest a variety of normative judgments about terrorism and the British state. Through a telephone survey of 1,003 Muslims sampled from the UK, Mirza et al. identify intergenerational increases in reported religiosity and little support for terrorist organizations. They report that $7 \%$ of respondents in their sample "admire organizations like Al-Qaeda" (Mirza et al. 2007). By contrast, a Gallup study based on a probability sample of London Muslims in late 2006 and early 2007, found Muslims in their sample as likely as members of the general public to condemn terrorist attacks on civilians and slightly more likely than the general public $(81 \%$ v. $72 \%)$ to find no moral justification for the use of violence in a "noble cause (Mogahed 2007)". These studies do not suggest that at least some U.K. Muslims maintain ideological 
postures that are particularly supportive of terrorism, but they do not directly examine the impact of Muslim ideologies upon cooperation with the police.

British Muslims also appear to have divergent judgments about the procedural justice and efficacy of the police. Muslim civil society groups argue that new policing powers created since 2000 are used in discriminatory ways based on religious identity or in ways that exacerbate private violence against Muslims (Birt 2006, Chakrabarti 2007; HCCLGC2010; Kundnani 2009). Robust empirical study of the consequences of the interaction between police and minority communities, however, has been in short supply. Mythen et al. conducted focus groups with 32 British Pakistanis aged 18-26 in northwest England and identified concerns about racial victimization and "excessive police stop searching (Mythen et al. 2009)." Based on field interviews, Haberfeld et al. also report confusion about the division of authority between local police and the security services in counter-terrorism and also a "disconnect between the law enforcement and the community (Haberfeld et al. 2009, 57)”. By contrast, an eleven-city European survey, including the English city of Leicester and the London borough of Waltham Forest, found levels of similar trust in police among Muslims and non-Muslims (OSI 2010, 169170). Based on focus groups conducted in conjunction with an eleven-city survey of Muslims in Europe, that study posited that trust in the police is high among European Muslims because of favorable comparisons between European police and police in a country of emigration (OSI 2010, 172; see also Loader and Mulcahy 2003, 162).

To summarize, past studies of British Muslims identify a population with an internal diversity of normative judgments about both terrorism and the British police. No previous study, however, has attempted to estimate the relationships between on the one hand, those judgments about the police and about terrorism, and on the other hand, cooperation with police that may 
mitigate the risk of terrorist events occurring. (For studies of the Israeli context see Jonathan 2010, Weisburd et al. 2010). This study exploits these relationships with the aim of identifying predictors of public cooperation with police in addressing terrorism.

\section{Method}

\section{A. Survey Methodology}

This cross-sectional study of Muslims in London was conducted in two stages. The first stage was designed to gather information concerning British Muslims' interactions with police in regard to terrorism. A snowball sample of one hundred non-quantitative, open-ended interviews was conducted with British Muslims in London. Interviewers were recruited through advertising in undergraduate and graduate faculties in Greater London. Data gathered through this nonrandom sample was used to inform the survey design at the second stage. For example, the openended survey was used to gather information about what members of the London Muslim community believed police to be doing to counter terrorism, the kind of foreign policy disputes that people believed most salient, and the distribution of contacts with law enforcement. This data was used in the design of a survey instrument for the second-stage randomly sampled part of the study. That data also includes material that can be used in the interpretation of quantitative data from the second stage.

In the second stage of the study, we conducted extended closed-ended interviews with a random sample of 300 individuals drawn from the population of Muslims residing in Greater London. This part of the study was conducted by the survey research firm SRBI and its Londonbased affiliate Ethnic Focus. The respondents were identified though the following random walk method. London boroughs were divided into three strata according to the proportion of 
population recorded as Muslim in the 2001 Census. Within each of these strata, boroughs were randomly drawn from a distribution weighted according to each one's concentration of the aggregate London Muslim population. Within each borough, one ward was randomly selected. Equal numbers of interviews were conducted in each ward. Within each ward, a random walk method was used to identify respondents. Beginning at a designated random starting point, interviewers followed a random route protocol to identify doors to knock on. Noncontacted residences were revisited twice on different days, at evenings and at weekends. Interviewers spoke English, Urdu, Arabic and Bengali. During the face to face contact the interviewer described the study and obtained cooperation from the respondent. They were then called back and interviewed over the telephone. This procedure was used to allay suspicion about the purposes of the study and to secure higher levels of cooperation from respondents. In addition a stratified sampling methodology was used to produce demographic variance along gender and age dimensions.

The procedure led to a high overall response rate of $81 \%$ using APPOR standard response rate definition three (A parallel study conducted in the United States with solely telephone contact and interviews obtained a response rate of 47\%, see Tyler, Schulhofer \& Huq, 2010). Ninety percent of the interviews were conducted in English; 3\% in Arabic; 5\% in Urdu and 2\% in Bengali.

Questions were drawn from two sources. First, previous studies of policing and legitimacy have developed questions to elicit views on deterrence and legitimacy (Tyler 2006b; Tyler \& Fagan 2008) and procedural justice (Tyler \& Fagan, 2008), measures adapted to counter-terrorism policing by Tyler, Schulhofer \& Huq (2010). Second, the qualitative pre-test was used in the design of the telephone survey instrument. 
Two methodological issues are of potential importance. First, whether the sample was comprised of respondents who were more likely than the average Muslim to speak to a survey researcher, and by extension more inclined to cooperate with police. We believe that this kind if sampling bias is unlikely given that the response rate for the survey of $81 \%$ using APPOR standard response rate definition three is high. The fact that it was a small proportion of individuals approached who declined to respond - the result of the random walk method of contacting respondents - makes it unlikely that the data suffers from a bias of this kind. On the contrary, the fact that respondents were initially approached in person and asked to cooperate in the study likely led the sample to be especially representative relative to typical telephone surveys.

Second, respondents were asked about whether they would engage in various forms of cooperation in the future; we report this below as data on "cooperation." We gathered no data, however, on what respondents would do if in fact presented with a situation in which cooperation with police was a possibility. To some extent such behavior is by definition unobservable, since there is no simple way to know that someone could have cooperated but decided not to do so. Further resource and ethical constraints make it infeasible to observe directly how respondents react to occasions for cooperation in practice. The incidence of terrorism is not high enough to be able to secure statistically significant data without very large samples. Further, obvious ethical concerns arise in simulating terrorism risks to text experimentally respondents' reactions. Data on expected cooperation is therefore the best data available. It is encouraging therefore that other studies have compared "self-reported" cooperation rates with independently observed behavior and found high levels of convergence (Blader and Tyler 2009; Tyler et al 2007) and that people's 
statements about their intentions to act are widely found to predict their subsequent behavior (Ajzen and Fishbein 1980).

\section{B. Demographics}

The mean age of the sample is 35 and $50 \%$ are male. The sample is diverse in terms of both income and education. For income $28 \%$ have an annual income of under $£ 20,000 ; 30 \%$ between 20 and 30,000 pounds; $24 \%$ between 30 and 40,000 pounds; $14 \%$ between 40 and 50,000 pounds; and 5\% over $£ 50,000$. With respect to education, $17 \%$ had some schooling; $25 \%$ had completed secondary education; $21 \%$ had spent some time at university; $29 \%$ had completed a first university degree; and 8\% some post-graduate or further professional education.

\section{C. $\quad$ Measures}

This section describes the questions in the survey instruments and, as relevant, the scales used in the analysis. Appendix A provides a more detailed description of the questions used to construct each scale used in this analysis. Respondents were asked a series of closed-ended questions concerning their beliefs about and experiences of policing against terrorism, the British state and its relationship to British Muslims, and the legitimacy of the means and ends of terrorism. A majority of questions elicited answers on a four-point scale. Responses were combined to form scales to provide measures of both dependent and independent variables.

The study is focused on two dependent variables that measure different forms of cooperation with the police. The first measured general cooperation with the police in respect to counter-terrorism ("Work with the police"). This is based on questions concerning respondents' willingness to attend voluntary interviews or meetings called by the police. The second measured specific cooperation, i.e., the willingness to report different potentially suspicious incidents ("Alert the police"). We asked respondents whether they would contact police if they learned of 
specific risk indicators, e.g., a neighbor constructing a bomb, visiting "radical" websites, or distributing al Qaeda literature. To control for differences in respondents' prior views about the seriousness of a terror related behavior, we weighted likelihood of alerting by the respondent's perception of an incident's seriousness. In this weighting respondents were given greater weight for a stronger willingness to report terror threats that they judge to be especially serious.

The instrumental model was tested primarily through two variables that measured on the one hand the perceived seriousness of the terrorism threat and on the other hand the effectiveness of police in addressing that threat. To test an alternative form of instrumental explanation, we also asked respondents whether they cooperated to avoid retaliation from the police.

The procedural justice model, as developed in previous studies, requires data on both judgments of legitimacy and procedural justice. We sought both kinds of data from respondents and report both below. In line with previous studies, two sets of questions measuring procedural justice were used. One set of questions looked at procedural justice in the process of policy formation. The other examined procedural justice in policy implementation. To measure legitimacy we asked respondents about two kinds of judgments. First, we asked about their feeling of obligation to obey the law and to defer to decisions made by legal authorities independent of sanction risks and experiences with punishment ("Legitimacy"), and trust and confidence in the police. Second, we measured identification with the police based on shared moral values. To do this, we used a scale of moral legitimacy constructed based on questions about the overlap in "values" between the respondent and the police ("Legitimacy-Moral"). We did so because it has been suggested that moral identification is important to police legitimacy in the United Kingdom (Jackson and Bradford, 2009). 
To measure ideology, we asked a series of questions to elicit respondents' views on three general questions. First, we identified foreign policy questions mentioned in the literature of terrorist organizations (Kepel and Milelli 2010), and sought views about those political questions. Second, we sought information about respondents' views about terrorism as a political strategy. Third, we obtained information about the strength of religious identification. Table 1c, discussed in more detail below, contains a list of the questions relevant to the three hypotheses tested in relation to ideology.

In addition to examining which of the three proposed mechanisms best explains general and specific cooperation with police, the survey instrument allowed a disaggregation and analysis of different policing tactics. This enables a more granular analysis of the interaction between policing choices and policed populations. Using exploratory factor analysis, we constructed three scales based on questions about respondents' perceptions of the frequency of different kinds of policing tactics. First, a scale was constructed that measured how frequently police are perceived to engage in intrusive measures without any reference to group identity, e.g., searching people on public transport or questioning people at their homes ("Person Targeted"). This measure is intended to identify the perceived incidence of policing tactics that simply single out and burden individuals. Second, a scale was constructed that aggregated measures of how much police are perceived as targeting based on ethnicity or religion, in other words against the respondents' own community (“Community Targeted”). This measure, by contrast, is intended to measure the perceived incidence of measures targeting groups qua groups. The third measure focused on the distinct concept of harassment, and builds on questions about perceptions of whether police threaten the use of excessive force against members of a respondent's community ("Harass"). 


\section{Results}

\section{A. Descriptive Statistics}

We begin by presenting descriptive statistics relevant to the three possible mechanisms (instrumental, normative, and ideological) and the two main independent variables tested (specific and general cooperation). The descriptive data demonstrate that the sample drawn has sufficient internal variation to enable examination of each of the three mechanisms. It also provides a useful overview of the population that is the focus of the study. Tables $1 \mathrm{a}, 1 \mathrm{~b}$ and $1 \mathrm{c}$ present descriptive data concerning the relationship between beliefs, attitudes and expected behaviors respecting the police. Tables $1 \mathrm{a}, 1 \mathrm{~b}$, and $1 \mathrm{c}$ report the distribution of responses to questions concerning the instrumental, the normative, and the ideological mechanisms respectively. This includes questions about police efficacy, the size of the terrorism threat, the fairness of police behavior, foreign policy judgments, views about terrorism, and religious identity. The first column of each table reports the percentage of respondents who either disagreed or strongly disagreed with a proposition; the second column reports the percentage of respondents who either agreed or strongly agreed.

Include Tables $1 \mathrm{a}, 1 \mathrm{~b}$, and $1 \mathrm{c}$ here.

Tables 1a, 1b, and 1c suggest that the sample has considerable internal variance respecting all of the independent variables of interest. In the case of instrumental variables, a high proportion of the respondents do not believe the risk of terrorist violence in the United Kingdom to be large. In light of the historical record of attacks and attempted attacks since 2005, this is a perhaps surprising result. The sample was more evenly split on judgments of police efficacy. The sample also splits roughly evenly when evaluating the fairness of police behavior. 
But a majority ( $82 \%)$ is inclined to view the police as a legitimate body whose decisions warrant deference.

Respecting ideological mechanisms, the data suggest that political opposition for the policies of the UK government is very strong among British Muslims in London. More than 95\% of respondents disagree with the decisions to use force in Afghanistan and to create a prison in Guantánamo Bay, while 70\% disagree with the invasion of Iraq. Almost all (98\%) disagree with support for Israel. By contrast, support for terrorism varies. Most respondents support the suggestion that terrorists have some valid grievances and many support terrorism itself, particularly for religious reasons. Finally, respondents reported strong identification with being Muslim and supported the idea of maintaining a separate culture. The sample thus generally identifies as religious. While the links between ideology and terrorism are empirically contested, this population nevertheless does seem to provide a context to conduct a strong test of the influence of various forms of ideology upon cooperation with the police against terrorism.

Tables $2 \mathrm{a}$ and $2 \mathrm{~b}$ turn to the dependent variables of interest-specific and general cooperation. We present first descriptive data showing the distribution of attitudes toward police.

Include Tables $2 \mathrm{a}$ and $2 \mathrm{~b}$ here.

Just as it is difficult to determine when ideology matters to the production of terrorism, so too it is difficult to say what level of cooperation is adequate and what level insufficient to maintain public order. More cooperation generally might be seen as better. But such cooperation will correlate to what the respondent views as legitimate police concerns, i.e., people will not report behavior that they do not feel should be a police concern. Table $2 \mathrm{a}$ and $2 \mathrm{~b}$ show that respondents clearly do not view all types of activity as equally of concern to the police. Table $2 \mathrm{a}$ indicates that a majority of the sample (64\%) are willing to volunteer and work with police. 
Table $2 \mathrm{~b}$ presents the data on specific cooperation. It demonstrates that there is a gap between what concerns respondents and what they are willing to report to the police. The most dramatic example of this gap arising in the respondences given to questions about knowing about a plan to plant explosives. In that case, $100 \%$ of respondents indicate that this is a proper police concern. But only $86 \%$ say that they would report the issue to the police. On another question, $35 \%$ of respondents indicate that someone withdrawing from a Mosque is a cause for police concern while only $20 \%$ would report it to the police. Hence, there is clearly some degree of reluctance to involve the police even when an issue might be evaluated as a legitimate police concern.

\section{B. What factors predict cooperation with the police within the sampled population of British} Muslims?

We turn next to the question of what best predicts the likelihood that members of the sampled population of British Muslims will state an intention to cooperate with the police. We address this question by using Ordinary Least Squares (OLS) regression to estimate the relationship between the two dependent variables of interest - general cooperation with police to fight terror and specific cooperation with police-and measures of the hypothesized instrumental, normative, and ideological mechanisms. We present multiple regression specifications in order to illustrate findings about the three hypothesized mechanisms.

Table 3 presents a simple specification. The dependent variables are specific and general cooperation in fighting terrorism. These are regressed against six indices and demographic variables (age, education, income, and gender): one corresponding to an instrumental mechanism, two corresponding to the procedural justice and legitimacy components of the normative mechanism; and three corresponding to the three hypothesized ideological variables. 
This parsimonious specification does not take account of covariation among variables reflecting different categories.

Insert Table 3 here.

Table 3 suggests first that the normative mechanism represented by procedural justice dominates both the instrumental mechanism and the various ideological mechanisms. This is so with respect to both general and specific cooperation. The data also suggests that legitimacy adds little to what is explained by procedural justice when considered alone.

Table 4 presents a more complex regression specification. Again, the dependent variables are general and specific cooperation. In this specification, more independent variables have been added to reflect different elements of each cluster (both specifications include demographics). All of the independent variables used in the model are listed in Table 4; they are also defined in Appendix A. Although this more complex specification allows for more precise estimation of the effects of different mechanisms, it also presents a greater risk of multicollinearity. Comparison of Table 3 to Table 4, however, allows us to identify possible multicollinearity problems.

Insert Table 4 here.

Table 4 indicates that both general cooperation and specific willingness to alert the police are centrally influenced by procedural justice judgments. Both the fairness of the procedure by which government forms anti-terror policing policies and the fairness of the procedures through which such polices are implemented shape cooperation. Instrumental factors appear to have no significant effect on cooperation. As before, these findings do not support the argument that people's ideologies — whether conceived in terms of political judgments, views about terrorism, or religiosity — shape their attitudes toward the police or the likelihood that they will cooperate with police in various ways. Ideology is generally irrelevant, as are background factors, 
including religion. The normative mechanism again emerges as the best explanation for cooperation in the population being studied.

Insert Table 5 here.

Table 5 confirms the link between procedural justice and cooperation through the use of a stepwise regression procedure. It also provides a sharper focus on the relationship between the two elements of the normative model - procedural justice and legitimacy. Table 5 indicates that once the influence of procedural justice is accounted for, legitimacy contributes nothing more to our understanding of cooperation. Further, once procedural justice is included neither ideology nor religion contribute additional variance. Hence, this analysis reinforces the conclusion that procedural justice is the key antecedent of cooperation.

Finally, Figure 1 summarizes presents the entire model. The model fit the data well (CFI $=0.95 ;$ RMSEA $=0.06$; Chi-square $(27)=56.8)$. As has been suggested, neither form of legitimacy directly shapes cooperation behavior. Instead, procedural justice directly shapes behavior and also influences legitimacy.

Insert Figure 1 here.

As has been noted, prior studies of procedural justice typically find that procedural justice influences upon cooperation are mediated by legitimacy. In this study of a British Muslim population, however, the influence of procedural justice on cooperation is direct and legitimacy is not found to mediate the relationship between procedural justice and cooperation. That finding is reinforced by the overall model shown in Figure 1. The implications of this finding will be addressed in the discussion.

C. What is the impact of changing police behavior? 
The centrality of procedural justice raises a further question of how the choice of policing measures influences perceptions of procedural justice. How the choice of tactics by police influences procedural justice judgments is clearly a salient question. The survey instrument allows for some further examination of that question. It included questions on respondents' beliefs about the frequency of different kinds of policing tactics. Table 6 therefore presents an exploratory factor analysis of the police behavior data.

Insert Table 6 here.

This analysis suggests that respondents categorize police behavior into three different categories. One reflects behaviors targeted toward the Muslim community. Another involves actions targeting particular individuals. And the third reflects harassment of Muslims.

Regression analysis was used to examine the influence of police actions upon legitimacy and procedural justice. The results of that analysis are shown in Table 7.

\section{Insert Table 7 here. [}

The results presented in Table 7 suggest that targeting individuals is evaluated as fair, while targeting communities is regarded as being illegitimate and unfair. Further harassment is viewed as illegitimate and unfair. Hence, the Muslim community clearly recognizes and accepts a role for the intrusion of legal authorities into their community but reacts negatively to actions viewed as directed at the community, not individuals and to harassment.

\section{Discussion}

The central aim of this study is to understand the circumstances in which members of the British Muslim community cooperated with police in counter-terrorism efforts. We hypothesized that there are three mechanisms that might explain such cooperation: an instrumental model, a 
procedural justice model, and three variations on "ideological" theories. The central finding of the study is that procedural justice concerns prove better predictors of cooperation of British Muslims in counter-terrorism policing than either instrumental or ideological mechanisms. Indeed we find no statistically significant relationship between either instrumental or ideological mechanisms and any form of cooperation, while procedural justice furnishes a consistently robust basis for explaining behavior. This result suggests that the procedural justice model developed in the context of studies of American policing has a broader scope. As discussed further below, however, the results of this study point to a different procedural justice mechanism than that observed in other studies, including a contemporaneous and parallel study of American Muslims.

At an initial matter, we found no support for either instrumental or ideological mechanisms in the production of police-community cooperation against terrorism. An instrumental model of cooperation could be supported by two different mechanisms. First, cooperation could be a product of the expected benefits of policing. Second, cooperation could be supplied as a strategy for avoiding the unwelcome policing measures. Our study finds no evidence of either. People in the sample do not cooperate with the police because they think the police are effective or the threat of terror is great. The second instrumental mechanism is also not supported by the findings of this study. The hypothesized mechanism would require police to dial down levels of harassment in the presence of cooperation. But the data shows, to the contrary, that when they feel harassed, people cooperate less. To defend instrumental mechanisms, it might be argued that the absence of observed relationships is due to free rider effects, whereby the broad distribution of benefits from cooperation means that the concentrated costs of cooperation are not rationally undertaken by a discrete community (Olson, 1971). But 
collective action logic cannot explain the observed significant variance in cooperation, or its correlation with non-instrumental factors.

We also hypothesized three possible mechanisms by which ideology could influence cooperation with the police based on views about (foreign policy) politics, terrorism or religion. Testing each of these three theories, this study finds no evidence to suggest that ideology has any role in producing cooperation against terrorism. British Muslims in London appear not to change their behavior in respect to the police as they diverge increasingly from the foreign policy decisions of the British government. Nor do they change their conduct as they come to more willingly endorse terrorism as a political tool,. Nor does self-identification as a Muslim (or not) appear to influence cooperation or a person's reported religiosity (or lack thereof) predict their attitude toward police. This last pair of findings parallels a finding in an analogous study of American Muslims, which also found no correlation between religiosity and cooperation (Tyler et al. 2010). It suggests that religiosity alone does not present a public order question, contrary to some conventional claims (Philips 2007).

Interestingly, the study finds no correlation between judgments about terrorism as an instrument of political change and the willingness to cooperate with law enforcement against terrorism. The failure to find any relationship of this kind is especially striking because, as Table 2c illustrates, the sample included a considerable range of view about terrorism. Nontrivial segments of the sample stated that terrorism could, in some instances, be justified. This belief did not appear to influence attitudes toward cooperation with the police. Although the data do not provide a precise explanation of this effect, it would seem that the sampled British Muslim population distinguishes between terrorism as a local threat and terrorism as an abstract idea: That terrorism may be justified in some instances does not entail that it is justified now and here. 
This suggests complex judgments about means-ends rationality, with violence being seen as more acceptable under some conditions. Those judgments present a potential subject of further inquiry.

Finally, the procedural justice model draws strong support from the results of this study. Both general and specific forms of cooperation were strongly predicted for this sample by procedural justice. While general cooperation was correlated with procedural justice at both the policy formation and the policy implementation stages, specific cooperation in the form of alerting the police was correlated primarily with procedural justice at the policy implementation stage.

These findings are consistent with other studies, including studies of Muslim American's interaction with counter-terrorism policing (Tyler et al. 2010), which have also failed to identify robust support for instrumental explanations of cooperation with law enforcement (or compliance with the law). The findings presented here also parallel the findings of a larger body of procedural justice literature respecting crime control (Tyler 2006b).

These results are subtly, but interestingly, divergent from results from a study by Tyler et al. of American Muslims' responses to counter-terrorism policing (Tyler et al. 2010). That study found that only procedural justice in policy formation influenced specific cooperation, but only procedural justice in implementation influenced general cooperation. In the counter-terrorism context, these results suggest, American and British Muslims negotiating with the state attend to different parts of the state's decision-making process. While American Muslims are focused on both policy formation and implementation (in different ways), British Muslims are focused more on policy formation. The data do not yield an explanation for the difference, but the gap is at least mildly suggestive of the distance between a society that protects interests though 
individualized assertion and rights-based judicial action and a society that defines rights and interests more through deliberative and legislative processes.

If British Muslims are attentive to the way in which policy is implemented, but even more attentive to the way it is formulated, this raises questions for further research. Our survey instrument did not examine perceptions of different mechanisms for community input and participation in policy formation. But the difference between various modalities of consultation, participation, and collaboration may warrant study. An example from a period prior to this study is illustrative. In the wake of the July 2005 bomb attacks in London, the Blair government established seven working groups that included members of the British Muslim community to investigate extremism and recommend initiatives to tackle it. The working groups were given six weeks to finish reports. Two weeks after they wound up, the government published a twelvepoint plan for responding to domestic terrorism. According to one Muslim member of the House of Lords who participated in the working groups, the latter were given too little time to develop a meaningful analysis. The government's twelve measures were also drafted "without waiting for [the working group] to come up with [its] recommendations, or indeed, [its] analysis of the problems (Oborne 2008, 129)." That government effort at community engagement was widely discounted as "shallow spin" and so may not have had a procedural justice effect (Oborne 2008, 130). While any negative effects from the working groups may well have worn off by the time of our study, it is worth asking more generally how different forms of consultation, perceived in different ways, can have different procedural justice effects. That is, if consultation is to part of the bundle of counter-terrorism policies, how can it be designed for best effect?

The results here also diverge in another important respect from the parallel study of American Muslims and from the body of procedural justice studies more generally. Unlike those 
studies, this study finds a gap between procedural justice and legitimacy. People in our sample do not view the police as more legitimate because they are fair and therefore cooperate more with the police. Rather, they looked directly to procedural justice without necessarily using that information to form a separate legitimacy judgment. In past studies the effect of procedural justice on cooperation and compliance has been found to be mediated by legitimacy (Tyler 2006b). That is, people appear to form normative judgments about the police based on perceptions of procedural justice, and it is these second-order judgments that are drawn upon when making cooperation and compliance decisions. The effect is not universal, and is not found in some studies conducted in China (Brockner et al. 2001). This study, by contrast, does find that procedural justice has a direct effect on cooperation but also finds that legitimacy does not have an intermediating role. That is, procedural justice predicts both cooperation and legitimacy, but legitimacy has no independent role in explaining cooperation.

The data provide no ready explanation for this result. One way to interpret this result, however, would focus on the perceived place of Muslims within British society and culture as a consequence of policies respecting the treatment and integration of migrant groups. British Muslim and their American counterparts are part of the same post-World War II migrant diasporas, but have been subject to different strategies of immigration and assimilation (Brown 2006; Shukla 2003). The procedural justice/legitimacy gap identified in this study may point to one downstream effect of those different immigration/integration/assimilation strategies. British Muslims, the data suggests, stand in British society but do not feel of British society. And the contrast with the parallel New York study suggests that they stand in this regard on different ground from American counterparts, who see themselves both in and of their society. So, for 
example, in this study identification with the UK does not predict cooperation, while in the parallel US sample identification with the US strongly predicts cooperation.

Those who identify with the overall society see themselves as having obligations to the state (Huo, 2003; Huo, Smith, Tyler \& Lind, 1996; Smith \& Tyler, 1996). They respond to the way the state behaves - and form long-term normative assessments of the state. The relationship of British Muslims to the state, by contrast, appears to be more contingent and less durable. Goodwill may be more strongly linked to personal connections and personal treatment by authorities. Levels of compliance and cooperation with police may also vary more depending upon experiences with state authority. The result bears further investigation, not merely as part of the procedural justice model, but also as part of an effort to understand the long-term effects of different migration and assimilation strategies.

\section{Conclusion}

The mechanisms of cooperation among British Muslims in efforts against terrorism importantly follow the procedural justice pathway identified in other literature. But they also diverge from the standard account because of the surprisingly minor role played by legitimacy. Whether there are distinctive psychological or sociological explanations for the divergence of the studied population is an important subject for further research.

\section{Funding}

This research was conducted with support from the Law and Social Science program of the U.S. National Science Foundation (NSF0751874). 


\section{Appendix A}

Cooperate with the police. Respondents were asked "How willing would you be to": "Work with the police to educate people in your community about the dangers of terrorists and terrorism?"; "To volunteer time on nights and weekends to help patrol areas of your community so as to help free police time to deal with anti-terror activities"; "To voluntarily attend a police call-in interview at a government office?:' "To encourage members of your community to generally cooperate with police efforts to fight terrorism?; and "To go to the police if you see dangerous terror related activity going on" (alpha $=0.61)$.

Alert the police. This variable was constructed by combining whether the respondent felt that the issue was a police concern and whether they would report the issue to the police.

Police concern. How concerned would you be about: "A person saying he or she had joined a group you consider politically radical"; "A person withdrawing from a mosque or another religious community without any explanation"; "A person overheard discussing their decision to help plant explosives in a terrorist attack": "A person visiting an internet chat room or web site in which there is material posted that supports al Qaeda"; "A person reading religious literature you believe to be extremist"; "A person giving money to organizations that people say are associated with terrorists"; "A person talking about traveling overseas to fight for Muslims"; and A person distributive material expressing support for al Qaeda" (alpha $=0.67$ )

Likelihood of reporting to the police. How likely would you be to report to the police: "A person saying he or she had joined a group you consider politically radical”; "A person withdrawing from a mosque or another religious community without any explanation"; "A person overheard discussing their decision to help plant explosives in a terrorist attack": "A person visiting an internet chat room or web site in which there is material posted that supports al Qaeda"; "A person reading religious literature you believe to be extremist"; "A person giving money to organizations that people say are associated with terrorists"; "A person talking about traveling overseas to fight for Muslims"; and A person distributive material expressing support for al Qaeda" (alpha $=0.75)$

Seriousness of terror risk. One question was asked. "Would you agree strongly, agree, disagee, or disagree strongly that" "There is a serious risk of a major terrorist attack in the UK."

Police performance. Two questions were asked: "How would you rate the police in terms of whether they are making you feel safe from the threat of terrorism?" and "If someone were 
planning a terrorist attack in London today, how likely do you think it is that they would be caught in advance" (alpha $=0.76)$.

Cooperate to prevent harm. One question was asked: "Some people think that if they do not help the police, the police will be more aggressive when they deal with the Muslim community. How often do you think this happens?".

The fairness of policy formation. Three questions were asked. The first two begin: "How much does the government involve your community when": "Making decisions about what actions to take to address the threat of terrorism in your community"; and "Trying to deal with problems in your community not related to terrorism". And "How often does the government convent meetings in your community to hear about community concerns about how the police should deal with the threat of terrorism?" (alpha $=0.76)$.

The fairness of policy implementation. Ten questions were asked reflecting overall procedural justice, quality of decision making and quality of interpersonal treatment (alpha $=$ 0.82). Respondents were asked to agree or disagree that when dealing with terrorism the police were fair: "In the procedures they use to handle the problems they deal with"; "How they treat people"; "In giving people a chance to express their views before making decisions"; "In accurately understanding and applying the law"; "In making their decisions based upon facts, not their personal opinions"; "In applying the law consistently to everyone"; "In considering people's views when deciding what to do"; "Taking account of the needs and concerns of the people they deal with"; "In respecting people's rights"; and "In treating people with dignity and respect".

Legitimacy. A six item scale was used. That scale combined obligation and trust \& confidence. The items were: "The police are legitimate authorities and you should obey their decisions"; "You should accept the decisions made by the police even when you disagree with them"; "It is our duty to obey the police even when we do not like the way they treat us"; "The police generally treat people with dignity and respect when they are investigating and prosecuting terrorism:"; "You trust the police to make decisions that are good for everyone when they are investigating and prosecuting terrorism": "People's rights are generally well protected by the police when they are investigating and prosecuting terrorism" (alpha $=0.68$ ). 
Morality. A two item scale was used: "The actions that the police take in dealing with terrorism are consistent with your own moral values"; and "Your own values about what is right and wrong agree with the laws and rules concerning how to deal with terrorism" (alpha $=0.69$ ).

Is terrorism immoral? Three questions were asked: "Some people think that suicide bombings and other forms of violence against civilian targets is sometimes justified to defend Islam against enemies. Do you think such violence is sometimes justified, is rarely justified or is never justified (reverse scored)"; "It is always morally wrong to commit a terrorist act that risks the lives of civilians"; and "Sometimes the long-term good to society that comes out of terrorist acts outweighs the short-terms hard to the particular people injured or killed (reverse scored)" $($ alpha $=0.64)$.

Are the ends of terrorism justified? One question was asked: "Do you personally think that terrorist violence undertaken for political reasons is sometimes justified, is rarely justified or is never justified?".

Support government foreign policies? Four questions were asked: "The U.K. made the right decision using military force in Afghanistan"; "Participation in the 2003 invasion and occupation of Iraq by the U.K. was necessary to combat threats of terrorism"; "Israel should withdraw all its troops and settlements from the territories it occupies on the West Bank"; and "The establishment of the American prison on Guantanamo Bay was morally wrong" (alpha = $.50)$.

Identification as a Muslim. Two questions were asked: "Being a Muslim is important to the way that I think of myself as a person"; and "I am proud to be Muslim" (alpha =.54).

Identification with the UK. Four questions were asked: "I am proud to be British"; "What the UK stands for is important to me"; "When someone praises the UK, it feels like a personal compliment to me"; and "Being British is important to the way that I think of myself as a person" (alpha $=.57)$.

Muslims should keep separate. Two questions were asked: "Muslims should try to keep a separate cultural identity"; and "Muslims in the UK today should try to remain distinct from the larger society" (alpha $=0.86)$.

How religious are you? Four questions were asked: "Would you say that religion is a very important part of your daily life"; "How often do you pray":' How often do you attend a 
mosque": and "How often do you take part in social or religious activities in a mosque or Islamic center" (alpha $=0.72)$.

Muslims are respected by the British. Respondents were asked "Do you think that nonMuslim British": "Respect how you live your life"; "Respect what you contribute to England"; and "Respect what you believe" (0.55).

Muslims are discriminated against in society. Three questions were asked: "At work or in schools"; "When dealing with authorities in public institutions"; and "In the media" (alpha = $0.42)$.

Have you changed your religious practices? Respondents were asked: "How much have your changed your religious practices because of concerns about how will be treated by others?": "Changed attendance at prayers?"; "Changed how you dress in public": "Altered your everyday activities?:' or "Changed your travel behavior” (alpha $=.82$ ).

Police actions directed at the person. "Search people on trains or the underground"; "Come to people's homes to ask questions"; and "Use informants from the community who are placed in mosques or community organizations" (alpha $=.72)$.

Police actions directed at the community. "Conduct electronic surveillance of mosques or community organizations"; "Single out people on the streets for questioning and searches based upon ethnicity/religion"; "Single out members of your ethnic or religious group for greater attention at immigration or at airport security"; "Listen to the telephone calls or read the e-mail of people in your community"; "Tracy money contributed to Islamic charities by people in your community"; "Pub people from your community on trial for terror related crimes"; and "Conduct raids on homes of people in your community to arrest people" (alpha $=.82)$.

Police harass Muslims. Would you agree or disagree that: “The police are especially suspicious of people from your community"; "Use too much force when dealing with people from your community"; "Threaten people from your community with physical harm"; and "Threaten to arrest or deport people from your community unless they cooperate" (alpha $=.60$ ).

Age. Respondents indicated the year they were born.

Education. Respondents indicated their level of education.

Income. Respondents reported annual family income.

Gender. The interviewer coded gender. 
Table 1a: Descriptive statistics: instrumental mechanisms

\begin{tabular}{|l|c|c|}
\hline \multicolumn{2}{|c|}{ Instrumental Reasons } \\
\hline $\begin{array}{l}\text { There is a serious risk of a major } \\
\text { terrorist attack in the United } \\
\text { Kingdom at this time. }\end{array}$ & $\begin{array}{c}\text { Disagree strongly/disagree } \\
80 \%\end{array}$ & $\begin{array}{c}\text { Agree strongly/agree } \\
20 \%\end{array}$ \\
\hline $\begin{array}{l}\text { It is likely that the police would } \\
\text { catch someone planning a } \\
\text { terrorist attack in London. }\end{array}$ & $\begin{array}{c}\text { Not at all likely/a little likely } \\
50 \%\end{array}$ & $\begin{array}{c}\text { Very/somewhat likely } \\
50 \%\end{array}$ \\
\hline
\end{tabular}

Table 1b: Descriptive statistics: normative mechanisms

\begin{tabular}{|c|c|c|}
\hline \multicolumn{3}{|c|}{ Normative Reasons } \\
\hline $\begin{array}{l}\text { The police generally treat people } \\
\text { with dignity and respect when } \\
\text { they are investigating and } \\
\text { prosecuting terrorism. }\end{array}$ & $\begin{array}{l}\text { Seldom/almost never } \\
54 \%\end{array}$ & $\begin{array}{l}\text { Usually/sometimes } \\
46 \%\end{array}$ \\
\hline $\begin{array}{l}\text { The government takes your } \\
\text { views and the views of your } \\
\text { community into account when } \\
\text { making decisions about what } \\
\text { actions to take to address the } \\
\text { threat of terrorism if those } \\
\text { actions affect your community. }\end{array}$ & $\begin{array}{c}\text { Not much at all/a little } \\
65 \%\end{array}$ & $\begin{array}{c}\text { A great deal/somewhat } \\
35 \%\end{array}$ \\
\hline $\begin{array}{l}\text { The police are legitimate } \\
\text { authorities and you should obey } \\
\text { their decisions. }\end{array}$ & $\begin{array}{c}\text { Disagree strongly/disagree } \\
18 \%\end{array}$ & $\begin{array}{c}\text { Agree strongly/agree } \\
82 \%\end{array}$ \\
\hline
\end{tabular}




\section{Table 1c: Descriptive statistics: three ideological mechanisms}

\begin{tabular}{|c|c|c|}
\hline \multicolumn{3}{|c|}{ Political Differences } \\
\hline $\begin{array}{l}\text { The UK made the right decision } \\
\text { using military force in } \\
\text { Afghanistan }\end{array}$ & $\begin{array}{c}\text { Disagree strongly/disagree } \\
96 \%\end{array}$ & $\begin{array}{c}\text { Agree strongly/agree } \\
4 \%\end{array}$ \\
\hline $\begin{array}{l}\text { Participation in the } 2003 \text { invasion } \\
\text { and occupation of Iraq by the UK } \\
\text { was necessary to combat threats } \\
\text { of terrorism }\end{array}$ & $\begin{array}{l}\text { Disagree strongly/disagree } \\
70 \%\end{array}$ & $\begin{array}{c}\text { Agree strongly/agree } \\
30 \%\end{array}$ \\
\hline $\begin{array}{l}\text { The establishment of the } \\
\text { American prison on Guantanamo } \\
\text { Bay was morally wrong }\end{array}$ & $\begin{array}{c}\text { Disagree strongly/disagree } \\
4 \%\end{array}$ & $\begin{array}{l}\text { Agree strongly/agree } \\
996 \%\end{array}$ \\
\hline $\begin{array}{l}\text { Israel should withdraw all its } \\
\text { troops and settlements from the } \\
\text { territories it occupies on the West } \\
\text { Bank }\end{array}$ & $\begin{array}{c}\text { Disagree strongly/disagree } \\
2 \%\end{array}$ & $\begin{array}{l}\text { Agree strongly/agree } \\
\qquad 98 \%\end{array}$ \\
\hline \multicolumn{3}{|c|}{ Judgments about Terrorism } \\
\hline $\begin{array}{l}\text { Terrorists often have valid } \\
\text { grievances }\end{array}$ & $\begin{array}{c}\text { Disagree strongly/disagree } \\
24 \% \\
\end{array}$ & $\begin{array}{c}\text { Agree strongly/agree } \\
76 \% \\
\end{array}$ \\
\hline $\begin{array}{l}\text { Terrorism is sometimes justified } \\
\text { to defend Islam }\end{array}$ & $\begin{array}{c}\text { Disagree strongly/disagree } \\
58 \% \\
\end{array}$ & $\begin{array}{c}\text { Agree strongly/agree } \\
42 \% \\
\end{array}$ \\
\hline $\begin{array}{l}\text { The long-term good of terrorism } \\
\text { sometimes outweighs the short } \\
\text { term harm }\end{array}$ & $\begin{array}{c}\text { Disagree strongly/disagree } \\
77 \%\end{array}$ & $\begin{array}{l}\text { Agree strongly/agree } \\
\qquad 23 \%\end{array}$ \\
\hline $\begin{array}{l}\text { Terrorism is sometimes justified } \\
\text { for political reasons }\end{array}$ & $\begin{array}{c}\text { Disagree strongly/disagree } \\
84 \% \\
\end{array}$ & $\begin{array}{c}\text { Agree strongly/agree } \\
16 \% \\
\end{array}$ \\
\hline $\begin{array}{l}\text { It is sometimes morally } \\
\text { acceptable to commit terrorist } \\
\text { acts }\end{array}$ & $\begin{array}{l}\text { Disagree strongly/disagree } \\
91 \%\end{array}$ & $\begin{array}{l}\text { Agree strongly/agree } \\
9 \%\end{array}$ \\
\hline \multicolumn{3}{|c|}{ Religious identity } \\
\hline $\begin{array}{l}\text { Being a Muslim is important to } \\
\text { the way you think of yourself as } \\
\text { a person }\end{array}$ & $\begin{array}{c}\text { Disagree strongly/disagree } \\
8 \%\end{array}$ & $\begin{array}{l}\text { Agree strongly/agree } \\
992 \%\end{array}$ \\
\hline $\begin{array}{l}\text { How strongly do you identify as } \\
\text { a Muslim }\end{array}$ & $\begin{array}{l}\text { Not at all/not very strongly } \\
38 \%\end{array}$ & $\begin{array}{c}\text { Very/somewhat strongly } \\
62\end{array}$ \\
\hline $\begin{array}{l}\text { Muslims in the UK today should } \\
\text { teach their children to adopt } \\
\text { British customs and ways of }\end{array}$ & $\begin{array}{c}\text { Disagree strongly/disagree } \\
79 \%\end{array}$ & $\begin{array}{l}\text { Agree strongly/agree } \\
21 \%\end{array}$ \\
\hline
\end{tabular}


Table 2a: Descriptive statistics: measures of general cooperation with law enforcement

\begin{tabular}{|c|c|c|}
\hline Cooperation & $\begin{array}{c}\text { Very/somewhat } \\
\text { unlikely }\end{array}$ & $\begin{array}{c}\text { Very/somewhat } \\
\text { likely }\end{array}$ \\
\hline $\begin{array}{c}\text { Work with the police to educate } \\
\text { people in your community about } \\
\text { the dangers of terrorism. }\end{array}$ & $52 \%$ & $48 \%$ \\
\hline $\begin{array}{c}\text { Volunteer time on nights or } \\
\text { weekends to help patrol areas of } \\
\text { your neighborhood. }\end{array}$ & $77 \%$ & $23 \%$ \\
\hline $\begin{array}{c}\text { Encourage members of your } \\
\text { community to cooperate with the } \\
\text { police. }\end{array}$ & $36 \%$ & $64 \%$ \\
\hline $\begin{array}{c}\text { Go to the police if you see } \\
\text { dangerous activity. }\end{array}$ & $13 \%$ & $87 \%$ \\
\hline
\end{tabular}

Table 2b: Descriptive statistics: measures of specific cooperation with law enforcement

\begin{tabular}{|c|c|c|c|c|}
\hline & \multicolumn{2}{|c|}{ Concerned? } & \multicolumn{2}{c|}{ Alert police? } \\
\hline Alert the police? & $\begin{array}{c}\text { Not at } \\
\text { all/not very }\end{array}$ & $\begin{array}{c}\text { Somewhat } \\
\text { /very }\end{array}$ & Unlikely & Likely \\
\hline $\begin{array}{c}\text { A person saying he/she had joined a } \\
\text { group you consider politically radical. }\end{array}$ & $58 \%$ & $42 \%$ & $63 \%$ & $37 \%$ \\
\hline $\begin{array}{c}\text { A person withdrawing from a mosque } \\
\text { without any explanation. }\end{array}$ & $65 \%$ & $35 \%$ & $80 \%$ & $20 \%$ \\
\hline $\begin{array}{c}\text { A person overheard discussing their } \\
\text { decision to help plant explosives in a } \\
\text { terrorist attack. }\end{array}$ & $0 \%$ & $100 \%$ & $14 \%$ & $86 \%$ \\
\hline $\begin{array}{c}\text { A person visiting internet chat rooms in } \\
\text { which material supporting al Qaeda is } \\
\text { presented. }\end{array}$ & $9 \%$ & $91 \%$ & $43 \%$ & $57 \%$ \\
\hline $\begin{array}{c}\text { A person reading extremist religious } \\
\text { literature. }\end{array}$ & $43 \%$ & $57 \%$ & $73 \%$ & $27 \%$ \\
\hline $\begin{array}{c}\text { A person giving money to organizations } \\
\text { that people say are associated with } \\
\text { terrorists. }\end{array}$ & $32 \%$ & $68 \%$ & $57 \%$ & $43 \%$ \\
\hline $\begin{array}{c}\text { A person talking about traveling overseas } \\
\text { to fight for Muslims. }\end{array}$ & $46 \%$ & $54 \%$ & $69 \%$ & $31 \%$ \\
\hline $\begin{array}{c}\text { A person distributing material expressing } \\
\text { support for al Qaeda. }\end{array}$ & $29 \%$ & $71 \%$ & $45 \%$ & $55 \%$ \\
\hline
\end{tabular}


Table 3: Predictors of specific and general cooperation: a simple specification

\begin{tabular}{|c|c|c|}
\hline & Cooperation & Alert the police \\
\hline Demographics & $0 \%$ & $0 \%$ \\
\hline Instrumental concerns & $6 \% * *$ & $3 \% *$ \\
\hline $\begin{array}{l}\text { Procedural justice and } \\
\text { legitimacy }\end{array}$ & $23 \% * * *$ & $17 \% * * *$ \\
\hline $\begin{array}{l}\text {--Procedural justice } \\
\text { alone }\end{array}$ & $22 \% * * *$ & $17 \% * * *$ \\
\hline --Legitimacy alone & $5 \% * * *$ & $7 \% * * *$ \\
\hline Ideology & $3 \% *$ & $3 \% *$ \\
\hline --Foreign policy & $0 \%$ & $0 \%$ \\
\hline --Terrorism & $2 \% *$ & $2 \% *$ \\
\hline $\begin{array}{l}\text {--Religious } \\
\text { identification }\end{array}$ & $2 \% *$ & $2 \% *$ \\
\hline Religion & $7 \% * * *$ & $0 \%$ \\
\hline Overall & $23 \% * * *$ & $14 \% * * *$ \\
\hline
\end{tabular}

Note. The overall percentage of variance in the case of alert is higher $(17 \%)$ for procedural justice alone than for all the variables (14\%). This happens because the results are adjusted for the number of independent variables in the equation and in the case of alerting the police there are many nonsignificant predictors in the overall equation. 
Table 4. OLS regression of indexes of instrumental, normative, and ideological mechanisms on specific and general cooperation

\begin{tabular}{|c|c|c|c|c|}
\hline & \multicolumn{2}{|c|}{ Cooperate } & \multicolumn{2}{|c|}{ Alert the police } \\
\hline Combined legitimacy & $.16^{*}$ & -- & $.23 * * *$ & -- \\
\hline \multicolumn{5}{|l|}{ Procedural justice } \\
\hline Policy formation & -- & $.21 * * *$ & -- & $.14 *$ \\
\hline Policy implementation & -- & $.31 * * *$ & -- & $.36^{* * *}$ \\
\hline \multicolumn{5}{|l|}{ Ideology } \\
\hline Terrorism is moral & $-.14^{*}$ & .13 & -.09 & .08 \\
\hline Terrorism is politically acceptable & .08 & .06 & .07 & .06 \\
\hline Evaluation of government policy & -.08 & -.09 & -.03 & -.05 \\
\hline Muslim identification & -.08 & -.04 & .01 & .05 \\
\hline UK identification & .01 & -.02 & .02 & .01 \\
\hline Muslims should keep separate & .04 & -.03 & .11 & .04 \\
\hline \multicolumn{5}{|l|}{ Instrumental factors } \\
\hline Terror is serious & -.13 & -.11 & -.01 & .01 \\
\hline Police are effective & -.03 & -.01 & -.02 & .01 \\
\hline Cooperation to avoid retaliation & .12 & .08 & .10 & .06 \\
\hline \multicolumn{5}{|l|}{ Religion } \\
\hline I am religious & .10 & .11 & .08 & .09 \\
\hline People respect Muslims & -.12 & -.07 & .01 & .04 \\
\hline $\begin{array}{l}\text { I have changed my religious practices } \\
\text { due to discrimination }\end{array}$ & .05 & -.01 & .10 & .04 \\
\hline Society discriminates against Muslims & $-.18 *$ & .11 & .02 & -.09 \\
\hline \multicolumn{5}{|l|}{ Demographics } \\
\hline Age & .00 & .03 & .05 & .06 \\
\hline Education & .03 & .03 & -.06 & -.06 \\
\hline Income & -.01 & -.01 & .07 & .06 \\
\hline Gender & -.06 & -.06 & .07 & .05 \\
\hline Total adjusted R.-sq. & $12 \%$ & $23 \%$ & $6 \%$ & $14 \%$ \\
\hline
\end{tabular}

Table 4 has four columns because within each dependent variable there are two equations. One looks at the influence of legitimacy. The other looks at the influence of the two measures of procedural justice. 
Table 5. Stepwise analysis of factors shaping cooperation.

\begin{tabular}{|c|c|c|c|c|c|}
\hline & $\mathbf{1}$ & $\mathbf{2}$ & $\mathbf{3}$ & $\mathbf{4}$ & $\mathbf{5}$ \\
\hline Demographics & $\mathrm{x}$ & $\mathrm{x}$ & $\mathrm{x}$ & $\mathrm{x}$ & $\mathrm{x}$ \\
\hline Instrumental variables & & $\mathrm{x}$ & $\mathrm{x}$ & $\mathrm{x}$ & $\mathrm{x}$ \\
\hline Procedural justice & & & $\mathrm{x}$ & $\mathrm{x}$ & $\mathrm{x}$ \\
\hline Legitimacy & & & & $\mathrm{x}$ & $\mathrm{x}$ \\
\hline Ideology and religion & & & & & $\mathrm{x}$ \\
\hline Adjusted R.-sq. & $0 \%$ & $3 \%$ & $24 \%$ & $24 \%$ & $24 \%$ \\
\hline
\end{tabular}

The dependent variable is a combined measure of cooperation. 
Table 6: Factor analysis of police behaviors

\begin{tabular}{|l|c|c|c|}
\hline & Community & Person & Harass \\
\hline Single out people to stop based on ethnicity. & 0.57 & -- & -- \\
\hline $\begin{array}{l}\text { Single out people at immigration and airports based upon } \\
\text { ethnicity. }\end{array}$ & 0.59 & -- & -- \\
\hline Conduct electronic surveillance of Mosques. & 0.55 & -- & -- \\
\hline $\begin{array}{l}\text { Listen to telephone calls or read e-mails from your } \\
\text { community. }\end{array}$ & 0.59 & -- & -- \\
\hline Trace money contributed to Islamic charities. & 0.76 & -- & -- \\
\hline Put people from the Muslim community on trial. & 0.70 & -- & -- \\
\hline Conduct raids of people in the Muslim community. & 0.72 & -- & -- \\
\hline Search people on trains or in underground. & -- & 0.75 & -- \\
\hline Come to people's homes and ask questions. & -- & 0.77 & -- \\
\hline Use informants to identify people in Mosques. & -- & 0.71 & -- \\
\hline Are especially suspicious of Muslims. & -- & -- & .48 \\
\hline Use too much force when dealing with Muslims. & -- & -- & .56 \\
\hline Threaten Muslims with physical harm. & -- & -- & .83 \\
\hline Threaten to arrest or deport Muslims. & -- & -- & .77 \\
\hline
\end{tabular}


Table 7: The impact of police behavior on procedural justice judgments

\begin{tabular}{|c|c|c|c|}
\hline & Police & $\begin{array}{c}\text { Procedural } \\
\text { justice of } \\
\text { policy } \\
\text { formation }\end{array}$ & $\begin{array}{c}\text { Procedural } \\
\text { justice of policy } \\
\text { implementation }\end{array}$ \\
\hline $\begin{array}{c}\text { Person targeted } \\
\text { behavior }\end{array}$ & .07 & $.22 * * *$ & .07 \\
\hline $\begin{array}{c}\text { Community } \\
\text { targeted behavior }\end{array}$ & .00 & $-.34 * * *$ & $-.14^{*}$ \\
\hline Harassment & $-.20^{* * *}$ & $-.13^{*}$ & $-.16^{* *}$ \\
\hline $\begin{array}{c}\text { Seriousness of } \\
\text { terror }\end{array}$ & .02 & -.03 & -.03 \\
\hline $\begin{array}{c}\text { Police } \\
\text { performance }\end{array}$ & --- & -.03 & $.21^{* * *}$ \\
\hline Adjusted R.-sq. & $3 \% *$ & $10 \% * * *$ & $9 \% * * *$ \\
\hline
\end{tabular}




\section{Figure 1: Full causal model}

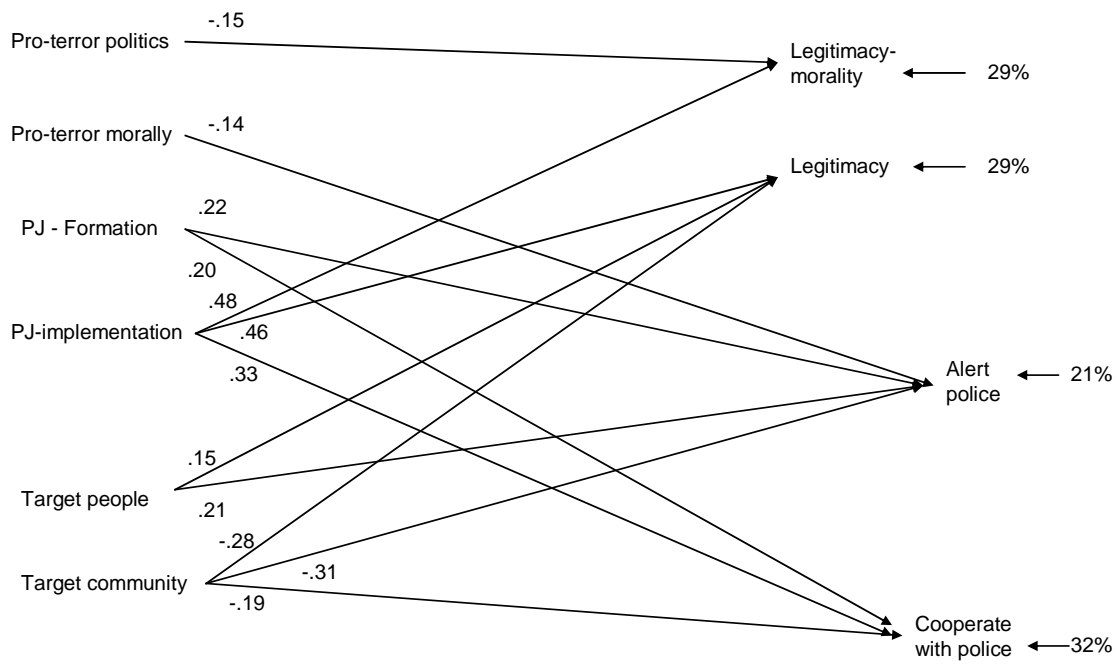

Figure 1. Full model. 


\section{Bibliography}

Ajzen, I \& Fishbein, M. (1980). Understanding attitudes and predicting social behavior. Englewood Cliffs, N.J.: Prentice Hall.

Ansari, H. (2004), The Infidel Within: Muslims in Britain Since 1800. London: C. Hurst.

Bayley, D., and Mendelsohn, H. (1969), Minorities and the police. New York: Free Press.

Becker, G. (1976), The Economic Approach to Human Behavior. Chicago: University of Chicago Press.

Bentham, J. (1996), An Introduction to the Principles of Morals and Legislation. New York: Oxford University Press.

Berrebi, C. and Klor, E. (2006), "On Terrorism and Electoral Outcomes," Journal of Conflict Resolution. 50: 899-925.

Blader, S. \& Tyler, T.R. (2009). "Testing and expanding the group engagement model” Journal of Applied Psychology, 94, 445-464.

Brockner et al. (2001). "Culture and Procedural Justice: The Influence of Power Distance on Reactions to Voice,” Journal of Experimental Social Psychology, 37(4), 300-315.

Brown, J. (2006). Global South Asians: Introducing the modern diaspora. Cambridge: Cambridge University Press.

Bureau of Justice Assistance (1994), Understanding Community Policing: A Framework for Action. Washington DC: U.S. Department of Justice Office of Justice Programs.

Chakraborti, N. (2007) "Policing Muslim Communities," in M Rowe (ed.) Policing Beyond Macpherson: Issues in Policing, Race and Society, Willan: Cullompton, 107-127.

Choudhury, T. et al. (2005), Muslims in the UK: Policies for Engaged Citizens. Budapest: Open Society Institute.

Clarke, P. (2007), Learning from experience: Counter-terrorism in the UK since 9/11. London: Policy Exchange.

Cronin, A. (2010). How Terrorism Ends: Understanding the Decline and Demise of Terrorist Campaigns. Princeton: Princeton University Press.

Donohue, L.K. (2008). The Cost of Counterterrorism: Power, Politics, and Liberty. Cambridge: Cambridge University Press.

Fetzer, J.S. and Soper, J.C. (2005). Muslims and the State in Britain, France, and Germany. New York: Cambridge University Press. 
Garland, D. (2001) The Culture of Control: Crime and Social Order in Contemporary Society. Chicago: University of Chicago Press.

Garoupa, N. Klick, J and Parisi, F. (2006), "A law and economics perspective on terrorism," Public Choice, 128: 147-168.

Haberfeld, M.R. King, J.F. and Lieberman, C.A. (2009), Terrorism within Comparative International Context: The Counter-terrorism Response and Preparedness. New York: Springer.

Habeck, M. (2007). Knowing the Enemy: Jihadist Ideology and the War on Terror. New Haven: Yale University Press.

Harcourt, B. (2001), Illusion of order: The false promises of broken windows policing: Chicago: University of Chicago Press.

Hasini, B. Geoffrey, G.A., and Flynn, D. (2009), "The Impacts of Policing Terrorism on Society: Lessons from Israel and the US", in D. Weisburd et al. eds, To Protect and to Service: Policing in an Age of Terrorism. New York: Springer.

HM Government. (2009). Delivering the Prevent Strategy: An Updated Guide for Local Partners. London: The Stationary Office.

HM Government. (2010). Pursue Prevent Protect Prepare: The United Kingdom's Strategy for Countering International Terrorism. London: The Stationary Office.

Hough, H. (2007), 'Policing, New Public Management, and Legitimacy in Britain", in T.R. Tyler, ed, Legitimacy and Criminal Justice: International Perspectives. New York: Russell Sage Foundation.

House of Commons Communities and Local Government Committee (2010), Preventing Violent Extremism: Sixth report of Sessions 2009-10. London: The Stationary Office.

Hughes, G. and Rowe, M. (2007), "Neighborhood policing and community safety," Criminology \& Criminal Justice. 7: 317-346.

Huo, Y.J. (2003). "Procedural justice and social regulation across group boundaries: Does subgroup identity undermine relationship based governance?" Personality and Social Psychology Bulletin, 29, 336-348.

Huo, Y.J., Smith, H.J., Tyler, T.R. \& Lind, E.A. (1996). “Superordinate identification, subgroup identification, and justice concerns: Is separatism the problem, is assimilation the answer?" Psychological Science, 7, 40-45.

Huq, A. (forthcoming 2011) "The signaling function of religious speech in domestic counterterrorism," Texas Law Review. 
Huq, A.Z., Tyler, T.R. and Schulhofer, S.J. (2011). How do the purposes and targets of policing influence the basis of public cooperation with law enforcement? Unpublished manuscript.

Jonathan, T. (2010), 'Police Involvement in Counter-Terrorism and Public Attitudes Toward the Police in Israel—1998-2007’, British Journal of Criminology, 50: 748-771.

Kennedy, Emmet. (1979). “'Ideology' from Destutt De Tracy to Marx, Journal of the History of Ideas," $40.3: 353-36$.

Kelling, G.L. and Bratton, W.J. (2006), Policing Terrorism. New York: Manhattan Institute.

Kelman, H.C. and Hamilton, V.L. (1989). Crimes of obedience. New Haven: Yale.

Kepel, G. (2004). The War for Muslim Minds: Islam and the West. Cambridge: Belknap Press.

Kepel, G. and Milelli, J-P. (2010). Al-Qaeda in its own words. Cambridge: Belknap Press.

Klandermans, B. (1997). The social psychology of protest. Oxford: Basil Blackwell.

Kundani, A. (2009). Spooked: How not to Prevent Violent Extremism. London: Institute of Race Relations.

LaFree, G. Dugan, L. and Korte, R. (2009), "The impact of British counterterrorist strategies on political violence in Northern Ireland: Comparing deterrence and backlash models", Criminology, 47, 17-45.

Lambert, R. (2008), "Empowering Salafis and Islamists against Al-Qaeda: A London Counterterrorism Case Study," PSOnline. January 2008,

Loader, I. and Mulcahy A. (2003), Policing and the Condition of England: Memory, Politics, and Culture. New York: Oxford University Press.

Lum, C. Haberfeld, M. Fachner, G. and Lieberman, C. (2009), "Police Activities to Counter Terrorism: What We Know and What We Need to Know," in D. Weisburd et al. eds, To Protect and to Service: Policing in an Age of Terrorism. New York: Springer.

MacCoun, R. (2005), "Voice, Control, and Belonging: The Double-Edged Sword of Procedural Fairness," Annual Review of Law and Social Science, 1: 171-201.

Mamdani, M (2005). Good Muslim, Bad Muslim: America, the Cold War, and the Roots of Terror. New York: Three Rivers Press.

Mayor of London. (2006). Muslims in London. London: Greater London Authority. 
McLaughlin, E. Muncie, J. and Hughes, G. (2001), The Permanent revolution: New Labor, New Public Management and the Modernization of Criminal Justice, Criminology and Criminal Justice, 1: 301-318.

Mythen, G. Walklate, S. and Khan F. (2009). "“I'm a Muslim, But I'm Not a Terrorist": Victimization, Risky Identities and the Performance of Safety," British Journal of Criminology, 49: 736-754.

Mirza, M. Senthilkumaran, A. and Ja'fer, Z. (2007), Living apart together: British Muslims and the paradox of multiculturalism. London: Policy Exchange.

Nagin, D. S. (1998), "Criminal deterrence at the onset of the $21^{\text {st }}$ century", Crime and Justice, 23: $1-42$.

Oborne, P. (2008), "The uses and abuses of terror: The construction of a false narrative on the domestic terror threat," in G. Kassimeris, ed. Playing Politics with Terrorism: A User's Guide. New York: Columbia University Press.

Olsen, M. (1971), The Logic of Collective Action: Public Goods and the Theory of Goods. Cambridge: Harvard University Press.

Open Society Institute. (2010), At Home in Europe: Muslims in Europe: A report on 11 EU cities. New York: Open Society Institute.

Pargeter, A. (2008). The New Frontiers of Jihad: Radical Islam in Europe. Philadelphia: University of Pennsylvania Press.

Philips, M. (2007). Londonistan. New York: Encounter Books.

Posner, R. (1985), "An Economic Theory of the Criminal Law", Columbia Law Review, 85, 1193-1231.

Reith, C. (1956), A New Study of Police History. London: Oliver \& Boyd.

Roy, O. (2004), Globalized Islam: The Search for a new Ummah. New York: Columbia University Press.

Roy, O. (2008). The Politics of Chaos in the Middle East. New York: Columbia University Press.

Sageman, M. (2004), Understanding Terror Networks. Philadelphia: University of Pennsylvania Press.

Sageman, M. (2008), Leaderless Jihad: Terror Networks in the Twenty-first Century. Philadelphia: University of Pennsylvania Press. 
Schulhofer, S., Tyler, T, and Huq, A. (forthcoming 2011). American Policing at a Crossroads: Unsustainable Policies and the Procedural Justice Alternative. Journal of Criminal Law and Criminology.

Shukla, S. (2003). India Abroad: Diasporic Cultures of Postwar America and England. Princeton: Princeton University Press.

Skogan, W.G. and Frydl, K. Eds. (2004), Fairness and Effectiveness in Policing: The Evidence. Washington, D.C.: The National Academies Press.

Smith, H.J. and Tyler, T.R. (1996). "Justice and power: Can justice motivations and superordinate categorizations encourage the advantaged to support policies which redistribute economic resources and encourage the disadvantaged to willingly obey the law?" European Journal of Social Psychology, 26, 171-200.

Sunshine, J. \& Tyler, T.R. (2003a), "The Role of Procedural Justice and Legitimacy in Shaping Public Support for Policing", Law and Society Review, 37: 513-547.

Sunshine, J. \& Tyler, T.R. (2003b), ’Moral Solidarity, Identification with the Community, and the Importance of Procedural Justice: The Police as Prototypical Representatives of a Group's Moral Values”, Social Psychology Quarterly, 66(2), 153-165.

Tanekebe, J. (2009), "Self-Help, Policing, and Procedural Justice: Ghanian Vigilantism and the Rule of Law," Law and Society Review, 43: 245-268.

Travis, A. (2010), "Illegal stop and searches could mean compensation for thousands", The Guardian. Manchester.

Turley, A. (2009). Stronger Together: A New Approach to Preventing Violent Extremism. London: New Local Government Network.

Tyler, T.R. (2000), "Social Justice: Outcome and Procedure," International Journal of Psychology, 35:117-125.

Tyler, T.R. (2005), "Policing in Black and White: Ethnic Group Differences in Trust and Confidence in the Police," Policing Quarterly. 8: 322-324.

Tyler, T.R. (2006a), "Psychological Perspectives on Legitimacy and Legitimation," Annual Review of Psychology. 57: 375:400.

Tyler, T.R. (2006b), Why people obey the law. Princeton: Princeton University Press.

Tyler, T.R. (2007a), Psychology and the Design of Legal Institutions. Nijmegen: Wolf Legal Publishers. 
Tyler, T.R. ed (2007b), Legitimacy and Criminal Justice: International Perspectives. New York: Russell Sage Foundation.

Tyler, T.R. (2009), “Legitimacy and criminal justice: The benefits of self-regulation”, Ohio State Journal of Criminal Law, 7: 307-359.

Tyler, T.R. and Fagan, J. (2008), 'Legitimacy and cooperation: Why do people help the police fight crime in their communities?" Ohio State Journal of Criminal Law, 6: 231-275.

Tyler, T.R. Lind, A.E. and Huo Y.J. (2000), "Cultural Values and Authority Relations: The Psychology of Conflict Resolution Across Cultures," Psychology, Public Policy, and Law. 6: 1138-63.

Tyler, T.R. and Huo, Y.J. (2002), Trust in the law. New York: Russell-Sage.

Tyler, T.R. Schulhofer, S.J. and Huq, A.Z. (2010). "Legitimacy and Deterrence Effects in Counter-Terrorism Policing: A Study of Muslim Americans", Law and Society Review, 44: 365401.

Tyler, T.R., Sherman, L.W., Strang, H., Barnes, G.C., and Woods, D.J. (2007). "Reintegrative shaming, procedural justice, and recidivism: The engagement of offenders' psychological mechanisms in the Canberra RISE drinking-and-driving experiment," Law and Society Review, 41(3), 553-586.

Walker, C. (2009), "Neighbor Policing and the All-Risks Policing of Terrorism", Journal of National Security Law and Policy, 3: 121-168.

Weber, M. (1968), Economy and society, Eds. G. Roth and C. Wittich, New York: Bedminster.

Weisburd, D. Hasisi, B. Jonathan, T. and Aviv, G. (2010), "Terrorist Threats and Police Performance", British Journal of Criminology, 50: 725-747.

Zimring, F. (forthcoming 2011). "The City that Became Safe: New York and the Future of Crime Control," Scientific American.

Readers with comments may address them to:

Professor Aziz Z. Huq University of Chicago Law School

1111 East 60th Street

Chicago, IL 60637

huq@uchicago.edu 


\section{The University of Chicago Law School Public Law and Legal Theory Working Paper Series}

For a listing of papers 1-275 please go to http://www.law.uchicago.edu/publications/papers/publiclaw.

276. Eric A. Posner and Adrian Vermeule, Tyrannophobia, September 2009

277. Bernard E. Harcourt, Henry Louis Gates and Racial Profiling: What's the Problem? September 2009

278. Lee Anne Fennell, The Unbounded Home, Property Values beyond Property Lines, August 2009

279. Brian Leiter, The Epistemic Status of the Human Sciences: Critical Reflections on Foucault, October 2009

280. Ward Farnsworth, Dustin F. Guzior, and Anup Malani, Ambiguity about Ambiguity: An Empirical Inquiry into Legal Interpretation, October 2009

281. Anup Malani, Oliver Bemborn and Mark van der Laan, Accounting for Differences among Patients in the FDA Approval Process, October 2009

282. Saul Levmore, Ambiguous Statutes, November 2009

283. Rosalind Dixon, Female Justices, Feminism and the Politics of Judicial Appointment: A Reexamination, November 2009

284. Rosalind Dixon, The Supreme Court of Canada, Charter Dialogue and Deference, November 2009

285. Rosalind Dixon, A Minimalist Charter of Rights for Australia: The U.K. or Canada as a Model? November 2009

286. F. Scott Kieff and Richard A. Epstein, Supreme Court Brief of Dr. Ananda Chakrabarty as Amicus Curiae in Support of Petitioners in Bilski (December 2009)

287. Jacob E. Gersen and Anne Joseph O'Connell, Hiding in Plain Sight? Timing and Transparency in the Administrative State (December 2009)

288. Richard A. Epstein, Impermissible Ratemaking in Health-Insurance Reform: Why the Reid Bill Is Unconstitutional (December 2009)

289. Brian Leiter, Why Legal Positivism? (December 2009)

290. Anu Bradford and Eric A. Posner, Universal Exceptionalism in Internatinal Law (February 2010)

291. Daniel Abebe and Eric A. Posner, Foreign Affairs Legalism: A Critique (February 2010)

292. Tom Ginsburg, Eastphalia as a Return to Westphalia (February 2010)

293. Tom Ginsburg, Lawrence Friedman's Comparative Law (February 2010)

294. Tom Ginsburg, Studying Japanese Law because It's There (February 2010)

295. Tom Ginsburg, Judicial Indipendence in East Asia: Implications for China (February 2010)

296. Tom R. Tyler, Stephen Schulhofer, and Aziz Huq, Legitimacy and Deterrence Effects in CounterTerrorism Policiing: A Study of Muslim Americans (February 2010)

297. Alison L. LaCroix, Federalists, Federalism, and Federal Jurisdiction (February 2010)

298. Brian Leiter, Rorty and the Philophical Tradition: A Comment on Professor Szubka (March 2010)

299. Aziz Z. Huq, Against National Security Exceptionalism (March 2010)

300. Anu Bradford, When the WTO Works, and How It Fails (March 2010)

301. Aziz Z. Huq, Modeling Terrorist Radicalization (March 2010)

302. Adam M. Samaha, On Law's Tiebreakers (March 2010)

303. Brian Leiter, The Radicalism of Legal Positivism (March 2010)

304. Lee Anne Fennell, Unbundling Risk (April 2010)

305. Aziz Z. Huq, What Good Is Habeas? (April 2010)

306. Aziz Z. Huq, Easterbrook on Academic Freedom (April 2010)

307. Jonathan S. Masur and Jonathan Remy Nash, The Institutional Dynamics of Transition Relief (April 2010)

308. Alison L. LaCroix, Temporal Imperialism (May 2010)

309. Lior J. Strahilevitz, Reunifying Privacy Law (May 2010) 
310. Lee Fennell, Possession Puzzles (June 2010)

311. Jonathan S. Masur, Booker Reconsidered (June 2010)

312. Mary Anne Case, What Feminists Have to Lose in Same-Sex Marriage Litigation (July 2010)

313. Mary Anne Case, A Lot to Ask: Review Essay of Martha Nussbaum's From Disgust to

Humanity: Sexual Orientation and Constitutional Law (July 2010)

314. Adam M. Samaha, The Story of FCC v. Pacifica Foundatin (and Its Second Life) (August 2010)

315. Jonathan S. Masur and Eric A. Posner, Climate Regulation and the Limits of Cost-Benefit Analysis (August 2010)

316. Jonathan Masur, Patent Inflation (August 2010)

317. Bernard E. Harcourt and Tracey L. Meares, Randomizaton and the Fourth Amendment (August 2010)

318. Adam M. Samaha, Low Stakes and Constitutional Interpretation (August 2010)

319. Brian Leiter, The Demarcation Problem in Jurisprudence: A New Case for Skepticism (August 2010)

320. Brian Leiter, Legal Formalism and Legal Realism: What Is the Issue? (August 2010)

321. John Bronsteen, Christopher Buccafusco, and Jonathan S. Masur, Retribution and the Experience of Punishment (September 2010)

322. Lior Strahilevitz, Pseudonymous Litigation (September 2010)

323. Bernard E. Harcourt, Risk As a Proxy for Race (September 2010)

324. Christopher R. Berry and Jacob E. Gersen, Voters, Non-Voters, and the Implications of Election Timing for Public Policy, September 2010

325. Lee Anne Fennell, Willpower Taxes, October 2010

326. Christopher R. Berry and Jacob E. Gersen, Agency Design and Distributive Politics, October 2010

327. Eric A. Posner, The Constitution of the Roman Republic: A Political Economy Perspective, November 2010

328. Tom Ginsburg, James Melton and Zachary Elkins, On the Evasion of Executive Term Limits, November 2010

329. Rosalind Dixon and Eric A. Posner, The Limits of Constitutional Convergence, November 2010

330. Tom Ginsburg, Constitutional Specificity, Unwritten Understandings and Constitutional Agreement, November 2010.

331. Tom Ginsburg, Written Constitutions and the Administrative State: On the Constitutional Character of Administrative Law, November 2010

332. Rosalind Dixon, Amending Constituting Identity, December 2010

333. Eric A. Posner and Adrian Vermeule, Demystifying Schmitt, January 2011

334. Jonathan S. Masur, Regulating Patents, January 2011

335. Bernard E. Harcourt, Reducint Mass Incarceration: Lessons from the Deinstitutionalization of Mental Hospitals in the 1960s, January 2011

336. Jacob E. Gersen, Designing Agencies, January 2011

337. Stephen J. Schulhofer, Tom R. Tyler, and Aziz Z. Huq, American Policing at a Crossroads, February 2011

338. Aziz Z. Huq, The Signaling Function of Religious Speech in Domestic Counterterrorism, February 2011

339. Aziz Z. Huq, Tom R. Tyler, and Stephen J. Schulhofer, Why Does the Public Cooperate with Law Enforcement? The Influence of the Purposes and Targets of Policing, February 2011

340. Aziz Z. Huq, Tom R. Tyler, and Stephen J. Schulhofer,Mechanisms for Eliciting Cooperation in Counter-Terrorism Policing: Evidence from the United Kindgdom 